\title{
PERAN MUHAMMADIYAH DALAM PENGEMBANGAN MASYARAKAT AGRARIS DI KABUPATEN BANDUNG
}

\author{
Utan Sahiro Ritonga ${ }^{1 *}$, Euis Evi Puspitasari ${ }^{2}$ \\ ${ }^{1}$ Program Studi Agribisnis, Fakultas Sains dan Teknologi, Universitas Muhammadiyah Bandung \\ ${ }^{2}$ Program Studi Ilmu Komunikasi, Fakultas Sosial Humaniora, Universitas Muhammadiyah \\ Bandung \\ Jl. Soekarno-Hatta No. 752 Bandung 40614 \\ *Corresponding author: utanritonga@umbandung.ac.id
}

\begin{abstract}
Community welfare is not only the responsibility of the central government but all parties according to their respective roles and functions. Considering that Indonesia is an agricultural country where most population works as farmers in rural areas, attention to developing farmer economic capacity is important in efforts to improve the welfare of the community. Muhammadiyah as a religious-based community organization has carried out its 'dakwah' role through the development of agrarian communities in rural areas. This study aims to determine farmers characteristics associated with the level of this role through a quantitative research approach. The testing technique in this study was carried out using three-box method and chi-square Pearson on survey data was collected non-probability with the technique as purposive samples. The results show that Muhammadiyah plays very significant role as a learning class, a forum for cooperation, and a production unit for farmers in Bandung Regency. Farmer's age, education level, length of farming, and income level had positively related, and group experience was negatively related to Muhammadiyah's role as learning class. Education level and length of farming had positive relationship, and farmer's income level had negative relationship with Muhammadiyah roles as production unit. Outstanding roles achievement from group to develop an agrarian society had a relationship with farmer characteristics that should be considered by interested parties for the farmer welfare, to achieve the role of group as an institution following the common ideals and expectations of farmers.
\end{abstract}

Keywords: agriculture development, community organization, farmer institution, farmer welfare

\begin{abstract}
Abstrak: Kesejahteraan masyarakat tidak hanya menjadi tanggung jawab pemerintah pusat tetapi semua pihak sesuai peran dan fungsinya masing-masing. Mengingat Indonesia merupakan negara agraris yang sebagian besar penduduknya bermata pencaharian sebagai petani di pedesaan, maka perhatian untuk mengembangkan kapasitas ekonomi petani menjadi penting dalam meningkatkan kesejahteraan masyarakat. Muhammadiyah sebagai organisasi masyarakat berbasis keagamaan telah melaksanakan peran dakwahnya melalui pengembangan masyarakat agraris di pedesaan. Penelitian ini bertujuan mengetahui karakteristik petani yang berkorelasi dengan tingkat peran tersebut melalui pendekatan penelitian secara kuantitatif. Teknik pengujian dalam penelitian ini dilakukan menggunakan three box method dan chi square pearson pada data survei yang dikumpulkan secara non probabilitas dengan teknik pengambilan sampel purposive. Hasil penelitian menunjukkan Muhammadiyah sangat berperan sebagai kelas belajar, wadah kerjasama, dan unit produksi bagi petani di Kabupaten Bandung. Usia petani, tingkat pendidikan, lama bertani, dan tingkat penghasilan berkorelasi positif, dan pengalaman berkelompok berkorelasi negatif dengan peran Muhammadiyah sebagai kelas belajar. Tingkat pendidikan dan lama
\end{abstract}


bertani berkorelasi positif, dan tingkat penghasilan petani berkorelasi negatif dengan peran Muhammadiyah sebagai unit produksi. Ketercapaian peran yang sangat baik dari sebuah kelompok untuk mengembangkan masyarakat agraris memiliki korelasi dengan karakteristik petani yang semestinya diperhatikan oleh pihak yang berkepentingan agar tercapai peran sebuah kelompok sebagai kelembagaan yang mampu mensejahterakan petani sesuai harapan semua pihak.

Kata kunci: pembangunan pertanian, organisasi masyarakat, kelembagaan petani, kesejahteraan petani

\section{PENDAHULUAN}

Ketertinggalan pembangunan masyarakat pedesaan seringkali kurang mendapat pemantauan pemerintah suatu daerah, sementara masyarakat memiliki akses informasi yang terbatas mengenai adanya program-program pembangunan. Adapun penyuluhan pembangunan yang dilaksanakan pemerintah menjadi kurang efektif untuk menjangkau seluruh masyarakat, sehingga tidak ada kesempatan masyarakat untuk menyalurkan aspirasi. Dalam hal ini karena umumnya pemerintah tidak mengambil langkah untuk memposisikan tokoh lokal sebagai komunikator, yang sebenarnya dapat memainkan peran yang cukup strategis sebagai agen pembangunan bagi masyarakat (Muchtar et al., 2013). Mengingat di tingkat desa/ kelurahan yang memiliki sumberdaya manusia bagi kesejahteraan sosial melalui penyuluh sosial masyarakat yang bersifat kerelawanan yang tidak terlembaga secara baik. Dengan begitu perangkat desa sebagai Kepala Urusan Kesra yang mengurus urusan sosial dirasakan masih kurang berperan dalam penyelenggaraan kesejahteraan sosial tersebut (Habibullah, 2020). Padahal perubahan sosial masyarakat dapat dilakukan oleh para agen yang terdiri dari organisasi, LSM, dan kelompok-kelompok tertentu dalam masyarakat yang memiliki bentuk birokrasi meliputi birokrasi publik dalam struktur pemerintahan dan birokrasi privat dalam bentuk organisasi swasta (Mulyadi, 2015).

Dalam buku "Model Dakwah Pencerahan Berbasis Komunitas” yang disampaikan dalam Muktamar Muhammadiyah ke 47 bahwa sebagai kelompok organisasi masyarakat Islam, Muhammadiyah melakukan gerakan pencerahan berikhtiar mengembangkan strategi dari revitalisasi ke transformasi untuk melahirkan berbagai amal usaha dan aksi-aksi sosial kemasyarakatan, yang berpihak pada kaum lemah dan tidak mampu secara ekonomi serta meningkatkan civil society (masyarakat madani) bagi kemajuan dan kesejahteraan bangsa.

Muhammadiyah dipandang memiliki pengaruh yang sangat kuat pada kalangan masyarakat menengah Indonesia, yang dapat dilihat dari luasnya cakupan reformasi organisasi yang tidak hanya bergerak untuk bidang pendidikan saja, melainkan beberapa bidang lainnya seperti menjadi pelopor dalam mendirikan panti, bank pengkreditan, rumah sakit dan sebagainya yang menjadi ciri masyarakat modern (Yusra, 2018). Berbagai bentuk amal usaha yang dibangun dan dikembangkan oleh Muhammadiyah ditengah masyarakat merupakan ujung tombak dari dakwah ekonomi, sosial, politik, kesehatan serta pendidikan (Jauhari, 2016).

Gerakan dakwah dewasa ini telah memasukan aktivitas penyampaian melalui pendidikan dan pengembangan masyarakat yang sesuai dengan nilai-nilai Islam, untuk semua orang tanpa memandang agamanya (Bungo, 2014). Paradigma dakwah pemberdayaan masyarakat bertujuan untuk mengubah keadaan ekonomi, sosial, budaya, pendidikan dan politik warga perdesaan. Peran serta pemerintah, masyarakat, pendakwah dan organisasi dakwah untuk menjembatani kegiatan dakwah dalam pemberdayaan masyarakat menjadi hal penting untuk disinergikan sehingga tujuan dakwah berhasil maksimal (Zaini, 2017).

Organisasi masyarakat yang selanjutnya disingkat ormas, saat ini tidak lagi menganggap pemerintah sebagai kekuatan yang mengekang kegiatan dan pergerakan ormas, tetapi sebaliknya memandang pemerintah sebagai bagian dari mitra yang dapat mengembangkan segenap potensi yang ada didalam ormas. Pemerintah melalui kegiatan ormas dapat 
melaksanakan pemberdayaan masyarakat yang mendukung kebijakan pemerintah (Mulyadi, 2012).

Pada sisi lain program-program pembangunan di sektor pertanian semakin sulit menjangkau petani kecil secara individu yang jumlahnya tersebar sangat banyak. Situasi ekonomi, kondisi infrastruktur, dan kebijakan dari pemerintah membawa petani dan buruh tani terdesak kearah marginalisasi ekonomi dan sosial. Selain penguasaan lahan pertanian yang semakin sempit, nilai tukar pertanian rendah, kebijakan pertanian yang tidak berpihak semakin mendorong petani pada keadaan semakin miskin yang mendorong kebutuhan wadah berkelompok bagi petani yang dapat memecahkan persoalan tersebut (Anantanyu, 2011).

Mengingat Indonesia merupakan negara agraris (Ardita et al., 2017), yang artinya sebagian besar penduduknya berprofesi sebagai petani (Hasan et al., 2016). Pada keadaan yang demikian itulah kemudian Muhammadiyah yang berada pada lokasi strategis dari kegiatan pertanian mengambil peran dakwahnya melalui program pemberdayaan petani. Meski pada pelaksanaannya tidak terdapat hubungan formal secara kelembagaan dalam bentuk struktural antara petani dengan pengurus Muhammadiyah, tetapi berbagai kegiatan untuk mendukung pengembangan masyarakat agraris dilaksanakan seperti fungsinya sebagai kelembagaan bagi petani. Untuk itu mengetahui peran dakwah Muhammadiyah dalam pengembangan masyarakat agraris menjadi semakin penting. Faktor yang berkorelasi dengan peran tersebut penting untuk diketahui agar dalam prosesnya dapat dipahami hal yang perlu diimplementasikan, agar tercapai pelaksanaan pengembangan masyarakat agraris lebih berhasil mensejahterakan petani.

Kinerja peran sebuah kelompok dalam pengembangan masyarakat agraris menurut tujuannya meliputi peran sebagai wadah kerjasama; kelas belajar; dan unit produksi yang dapat diukur secara kuantitatif untuk menentukan nilai perolehan dibandingkan dengan tingkat kategori (Palar et al., 2019; Pratama et al., 2016) atau berdasarkan nilai interval (Prasetia et al., 2015). Kinerja peran sebuah kelompok meliputi wadah kerjasama; kelas belajar; dan unit produksi memiliki korelasi dengan karakteristik petani yang dapat diuji menggunakan rank spearman (Ramadoan et al., 2013), atau menggunakan uji fisher's exact (Wati et al., 2020). Sementara penggunaan uji chi-square Pearson $\left(\chi^{2}\right)$ secara bersamaan dengan uji gamma $(\gamma)$ dalam menguji korelasi akan mengetahui nilai keeratan korelasi yang bersifat positif atau negatif dengan tingkat ketelitian yang lebih tinggi (Simanjuntak et al., 2018)

Adapun karakteristik petani dalam penelitian peran sebuah kelompok terdiri dari umur, pendidikan formal, pendidikan nonformal, persepsi anggota terhadap kepemimpinan dan kerjasama kelompok, pengalaman usahatani, motivasi, akses anggota terhadap informasi, dan keterlibatan anggota terhadap kelompok (Yani et al., 2010). Dengan pertimbangan bahwa hubungan antara petani terhadap ormas Muhammadiyah tidak melekat secara kelembagaan petani yang bersifat formal, melainkan hanya hubungan yang bersifat organisasi keagamaan dan tidak seperti pada penelitian lainnya, maka penelitian ini hanya menggunakan beberapa karakteristik petani yang disebutkan oleh Sofiyudin et al., (2016) yaitu umur, pendidikan formal, pendidikan nonformal atau oleh Damanik (2013) disebut sebagai pengalaman berkelompok, dan (Safitri et al., 2020) menyertakan lama bertani sebagai salah satu karakteristik petani. Demikian dengan pendapatan petani sebagai salah satu karakteristik anggota sebuah kelompok yang banyak diteliti seperti yang dilakukan oleh Wati et al. (2020). Mengingat pesatnya pembangunan di Kabupaten Bandung berupa perumahan, industri dan perkantoran yang menyebabkan alih fungsi tanah pertanian ke nonpertanian (Sidipurwanty, 2016) sehingga status kepemilikan lahan yang merupakan karakteristik petani anggota sebuah kelompok perlu diukur hubungannya dengan peran sebuah kelompok (Ramadoan et al., 2013), yang meliputi status sebagai petani penggarap, penyewa maupun pemilik (Manatar et al., 2017). Mengetahui hubungan karakteristik tersebut menjadi penting bagi organisasi dan lembaga sejenis lainnya, untuk melaksanakan fungsinya sebagai kelembagaan yang berperan dalam mendorong perkembangan masyarakat agraris di Indonesia. 
Ritonga, U. S., Puspitasari, E. E. : Peran Muhammadiyah Dalam Pengembangan ...

\section{METODE PENELITIAN}

Penelitian ini menurut klasifikasi teknik pengumpulan data yang digunakan adalah penelitian kuantitatif melalui pendekatan penelitian survei dengan kuesioner sebagai instrumen penelitian. Pengambilan sampel dilakukan secara non probabilitas dengan teknik penarikan sampel purposive atau secara tidak acak dengan membuat kriteria tertentu untuk kemudahan (Priyono, 2016). Kriteria sampel untuk kemudahan yang dimaksud adalah petani yang pernah terlibat program pemberdayaan petani yang dilaksanakan oleh pengurus Muhammadiyah di Kabupaten Bandung yang jumlahnya pada saat penelitian ini dilakukan mencapai 75 orang petani.

Adapun indikator peran Muhammadiyah dalam pengembangan masyarakat agraris di Kabupaten Bandung meliputi beberapa peran sebagai sebuah kelompok seperti yang disebutkan (Palar et al., 2019) sebagai berikut:

1. Peran sebagai kelas belajar terdiri dari: Meningkatkan produktifitas untuk menambah pendapatan (X1); Menumbuhkembangkan kemandirian dalam berusaha tani (X2); Wadah belajar mengajar bagi petani guna meningkatkan pengetahuan, sikap dan keterampilan (X3).

2. Peran sebagai unit kerjasama terdiri dari: Bekerja sama dalam menghadapi ancaman, tantangan, hambatan dan gangguan (X4); Tempat untuk memperkuat kerjasama antar kelompok tani serta dengan pihak lain (X5); Tempat untuk memperkuat kerjasama diantara sesama petani (X6).

3. Peran sebagai unit produksi terdiri dari: Mencapai skala ekonomi secara bersama dengan menyeimbangkan hasil produk dari segi kuantitas, kualitas maupun kontinuitas (X7); Mengembangkan usaha tani yang dilakukan secara bersama sebagai suatu kesatuan usaha bersama (X8); Mengembangkan usaha tani yang dilakukan oleh masyarakat (X9).

Pengukuran tingkat peran dilakukan dengan menghitung skor tiap indikator peran menggunakan notasi matematik (Palar et al., 2019):

$x=(1 \times \mathrm{n}+2 \times \mathrm{n}+3 \times \mathrm{n})$
Keterangan:

$x=$ Skor pada indikator

$\mathrm{n}=$ Jumlah jawaban

Skor yang diperoleh dari tiap indikator pertani kemudian diklasifikasikan kedalam kategori yang ditentukan menggunakan notasi matematik (Palar et al., 2019) dengan tidak memasukan jumlah instrumen dalam perhitungan pada rumus berikut:

$r=\frac{\text { nilai skor } \max -\text { nilai skor } \text { min }}{\text { jumlah kategori }}$

Dimana $\mathrm{r}=$ rentang nilai

Rentang nilai diperoleh dengan perhitungan skor maksimal yakni 3 sebagai pilihan jawaban tertinggi dikali jumlah responden dalam penelitian ini sebanyak 75 , dan dikurangi skor minimal yakni 1 sebagai pilihan jawaban terendah dikali jumlah responden, kemudian dibagi 3 sebagai kategori yang diinginkan sehingga 225-75/3 = 50 merupakan rentang skor kategori peran menjadi berikut:

Tidak Berperan $\quad=75-124$

Kurang Berperan $=125-174$

Sangat Berperan $=175-225$

Sementara karakteristik petani yang akan diteliti terdiri dari Usia petani (Y1), Tingkat pendidikan (Y2), Lama bertani (Y3), Status kepemilikan lahan (Y4), Tingkat penghasilan (Y5), Pengalaman berkelompok (Y6) yang diduga berkorelasi dengan peran Muhammadiyah sebagai sebuah kelompok bagi masyarakat agraris. Peran sebuah kelompok tersebut meliputi peran sebagai wadah kerjasama; peran sebagai kelas belajar; dan peran sebagai unit produksi yang berkorelasi dengan karakteristik petani dapat diuji menggunakan rank spearman (Ramadoan et al., 2013) tetapi pada penelitian ini menggunakan uji chi-square Pearson:

$x^{2}=\sum \frac{\left(F_{o}+F_{e}\right)^{2}}{F_{e}}$

Persamaan (3) tersebut untuk membuktikan hipotesis sebagai berikut:

Ho = terdapat korelasi antara karakteristik petani yang diteliti dengan indikator 


\author{
peran Muhammadiyah dalam \\ pengembangan masyarakat agraris. \\ $\mathrm{Ha}=$ tidak terdapat korelasi antara \\ karakteristik petani yang diteliti dengan \\ indikator peran Muhammadiyah dalam \\ pengembangan masyarakat agraris.
}

Apabila ditemukan cell atau kotak dengan nilai frekuensi harapan (expected frequency) kurang dari 5, maka distribusi sampling statistik chi-square Pearson kurang baik dalam hal mendekati distribusi chi-square dan menyebabkan data tidak akurat. Untuk menghindari hal tersebut dapat digunakan dengan melihat nilai Exact Sig. (2-sided) (bukan kolom Asymp.Sig. 2-sided). Exact Sig. (2-sided) yang merupakan hasil sebenarnya dengan mengabaikan syarat frekuensi harapan harus > 5 (Gio dan Caraka, 2018). Untuk itu kriteria pengujian pada penelitian ini dengan taraf nyata $\alpha=0,5$ :

- Jika Exact.Sig. (2-sided) < 0,05 maka $\mathrm{H}_{\mathrm{o}}$ diterima dan $\mathrm{H}_{\mathrm{a}}$ ditolak.

- Jika Exact.Sig. (2-sided) > 0,05 maka $\mathrm{H}_{\mathrm{o}}$ ditolak dan $\mathrm{H}_{\mathrm{a}}$ diterima.

Selanjutnya dilakukan uji gamma( $\gamma)$ untuk mengetahui arah dan keeratan korelasi tiap karakteristik terhadap indikator yang diukur. Adapun angka koefisien gamma menurut (Simanjuntak et al., 2018) terbagi atas beberapa kriteria yang dikelompokkan sebagai berikut:

- Jika $\gamma+/$ - diantara 0,10 sampai 0,29 terdapat korelasi lemah.

- Jika $\gamma$ +/- diantara 0,30 sampai 0,69 terdapat korelasi sedang.

- Jika $\gamma+$-- diantara 0,70 sampai 1 terdapat korelasi kuat.

\section{HASIL DAN PEMBAHASAN}

Pembentukan aktivitas sebuah kelompok didasari adanya kesamaan berbagai persoalan yang dihadapi para petani (Latifarruhma et al., 2019). Pada pasal 1 ayat 1 Permentan No. 67 tahun 2016 menyebutkan bahwa kelembagaan petani ditumbuhkembangkan dari, oleh dan untuk petani guna memperjuangkan kepentingan petani. Peran sebuah kelompok sebagai kelas belajar, unit kerjasama, dan unit produksi memengaruhi usaha tani petani yang terlibat. Untuk itu strategisnya posisi sebuah kelompok sebagai wadah dalam memberdayakan petani tercermin pada peran tersebut yang perlu kiranya mendapat perhatian (Nugroho et al., 2018). Hasil pengujian pada data penelitian ini menunjukkan peran Muhammadiyah sebagai kelembagaan untuk mengembangkan masyarakat agraris di Kabupaten Bandung meliputi peran sebagai kelas belajar, unit produksi dan unit kerjasama. Pengumpulan data dilakukan di 4 Kecamatan yang merupakan daerah tempat pelaksanaan kegiatan dakwah Muhammadiyah terdiri dari Kecamatan Kertasari, Kecamatan Pangalengan, Kecamatan Cikancung dan Kecamatan Paseh.

Dalam penelitian ini peran sebuah kelompok sebagai kelas belajar memiliki tujuan untuk meningkatkan pengetahuan, sikap dan keterampilan petani agar lebih mandiri dalam meningkatkan produktifitas dan menambah pendapatan. Hasil analisis tingkat peran Muhammadiyah sebagai kelas belajar bagi petani di Kabupaten Bandung dapat dilihat pada Tabel 1.

Berdasarkan Tabel 1 diketahui keberadaan Muhammadiyah sebagai kelas belajar sangat berperan dalam meningkatkan produktifitas untuk menambah pendapatan petani yang dilakukan dengan menyediakan

Tabel 1. Peran Muhammadiyah sebagai kelas belajar

\begin{tabular}{|c|c|c|c|c|c|c|}
\hline \multirow{2}{*}{ No } & \multirow{2}{*}{ Indikator } & \multicolumn{4}{|c|}{ Tingkat Peran } & \multirow{2}{*}{ Kesimpulan } \\
\hline & & 3 & 2 & 1 & Total & \\
\hline 1 & $\begin{array}{l}\text { Meningkatkan produktifitas untuk menambah } \\
\text { pendapatan (X1) }\end{array}$ & 31 & 42 & 2 & 179 & $\begin{array}{l}\text { Sangat } \\
\text { Berperan }\end{array}$ \\
\hline 2 & $\begin{array}{l}\text { Menumbuhkembangkan kemandirian dalam } \\
\text { berusaha tani (X2) }\end{array}$ & 26 & 47 & 2 & 174 & $\begin{array}{l}\text { Kurang } \\
\text { Berperan }\end{array}$ \\
\hline 3 & $\begin{array}{l}\text { Wadah belajar mengajar bagi petani guna } \\
\text { meningkatkan pengetahuan, sikap dan } \\
\text { keterampilan (X3) }\end{array}$ & 33 & 41 & 1 & 183 & $\begin{array}{l}\text { Sangat } \\
\text { Berperan }\end{array}$ \\
\hline
\end{tabular}

Sumber: Data Primer, 2020 
bantuan bibit melalui koperasi milik Muhammadiyah Kabupaten Bandung. Tetapi Muhammadiyah kurang berperan dalam menumbuhkembangkan kemandirian dalam berusaha tani karena hal tersebut membutuhkan waktu pada prosesnya yang harus dilakukan secara bertahap, dan dengan mempertimbangkan usia produktif, tingkat pendidikan dan pengalaman petani. Peran dalam menumbuhkembangkan kemandirian petani akan meningkat dimasa yang akan datang seiring proses dan pelaksanaannya. Adapun Muhammadiyah di Kabupaten Bandung telah sangat berperan dalam meningkatkan pengetahuan, sikap dan keterampilan dilakukan melalui program pemberdayaan masyarakat dengan menjalin kerjasama pada perguruan tinggi di Jawa Barat. Mengingat pelaksanaan kegiatan pertemuan secara rutin sebuah kelompok tani yang bersifat formal seringkali mulai jarang dilakukan, dan pelaksanaan kegiatan penyuluhan dari pihak luar tidak lagi direncanakan dengan baik (Wardani, 2017). Akibatnya peran sebagai kelas belajar tersebut tidak mampu menumbuhkan kemandirian petani seperti yang dinilai petani terhadap Muhammadiyah di Kabupaten Bandung. Untuk meningkatkan peran Muhammadiyah sebagai kelas belajar perlu meninjau karakteristik petani yang memiliki hubungan dengan indikator peran sebuah kelompok sebagai kelas belajar.

Adapun hasil pengujian terhadap karakteristik petani yang diduga berkorelasi dengan peran Muhammadiyah sebagai kelas belajar menurut uji chi-square Pearson dapat dilihat pada Tabel 2.
Hasil pengujian yang dapat dilihat pada Tabel 2 menunjukkan usia petani (Y1) terhadap X3 memiliki nilai ExactSig. (2-sided) 0,026 < 0,05 maka $\mathrm{H}_{0}$ diterima dan $\mathrm{H}_{\mathrm{a}}$ ditolak pada taraf nyata $95 \%$ dengan nilai koefisien gamma 0,165 , yang berarti terdapat korelasi positif yang lemah dimana peningkatan peran Muhammadiyah dalam meningkatkan pengetahuan, sikap dan keterampilan (X3) mengikuti peningkatan jumlah petani berusia produktif. Petani dengan usia produktif berada antara usia 25-49 tahun yang memiliki kemampuan untuk mencapai keberhasilan pengelolaan usahanya, karena adanya tanggungjawab secara ekonomi terhadap kebutuhan keluarga yang mendorong petani melakukan berbagai upaya pengembangan usahataninya yang diantaranya dapat dilakukan dengan melibatkan diri pada kelompok tertentu. Petani berusia muda memiliki cara berpikir yang lebih kreatif dengan kondisi fisik yang lebih kuat (Impal et al., 2017). Semakin banyak petani berusia produktif yang mengelola usaha tani akan meningkatkan peran Muhammadiyah dalam peningkatan pengetahuan, sikap dan keterampilan masyarakat agraris.

Tingkat pendidikan (Y2) terhadap X2 memiliki nilai ExactSig. (2-sided) 0,008 <0,01 maka $\mathrm{H}_{0}$ diterima dan $\mathrm{H}_{a}$ ditolak pada taraf nyata 99\% dengan nilai koefisien gamma 0,494, yang berarti terdapat korelasi positif yang sedang, dimana peningkatan peran Muhammadiyah untuk menumbuhkembangkan kemandirian dalam berusaha tani (X2) mengikuti peningkatan jumlah petani dengan tingkat pendidikan yang lebih tinggi.

Tabel 2. Uji Chi-square dan Gamma peran Muhammadiyah sebagai kelas belajar

\begin{tabular}{|c|c|c|c|c|c|c|}
\hline \multirow{3}{*}{ Karakteristik } & \multicolumn{6}{|c|}{ Peran Sebagai Kelas Belajar } \\
\hline & \multicolumn{2}{|c|}{ X1 } & \multicolumn{2}{|c|}{$\mathrm{X} 2$} & \multicolumn{2}{|c|}{ X3 } \\
\hline & $\begin{array}{l}\text { Exact Sig. } \\
\text { (2-sided) }\end{array}$ & Gamma & $\begin{array}{l}\text { Exact Sig. } \\
\text { (2-sided) }\end{array}$ & Gamma & $\begin{array}{l}\text { Exact Sig. } \\
\text { (2-sided) }\end{array}$ & Gamma \\
\hline Usia Petani & 0,069 & 0,086 & 0,096 & 0,284 & $0,026^{*}$ & 0,165 \\
\hline Tingkat Pendidikan & 0,299 & 0,330 & $0,008 * *$ & 0,494 & 0,224 & 0,412 \\
\hline Lama Bertani & 0,249 & 0,203 & 0,159 & 0,433 & $0,042^{*}$ & 0,306 \\
\hline Kepemilikan Lahan & 0,464 & 0,163 & 0,630 & 0,057 & 0,886 & $-0,158$ \\
\hline Tingkat Penghasilan & 0,296 & 0,012 & 0,079 & 0,117 & $0,050 *$ & 0,143 \\
\hline Pengalaman Berkelompok & $0,021 *$ & $-0,595$ & 0,098 & $-0,448$ & 0,431 & $-0,227$ \\
\hline
\end{tabular}

Sumber: Data Primer, 2020

\footnotetext{
Keterangan:

*signifikan $\alpha=0,05$

** signifikan $\alpha=0,01$
} 
Petani dengan pendidikan yang tinggi adalah petani dengan tingkat pendidikan minimal sekolah menengah atas (SMA) sederajat yang lebih mudah dalam memahami informasi dan lebih terbuka menerima pengarahan, serta dapat dengan cepat mengimplementasikan masukan dari pihak lain. Memang usaha bidang pertanian membutuhkan keterampilan tetapi tingkat pendidikan berkorelasi secara positif dengan pola pikir untuk memecahkan masalah (Nugroho et al., 2018). Tingkat pendidikan formal juga akan memengaruhi pembentukan perilaku, pola berpikir, tingkat kreatifitas, serta berbagai keterampilan melakukan usahatani maupun kehidupan (Yani et al., 2010) dan merupakan indikator kemampuan seseorang untuk segera dapat menyelesaikan pekerjaan atau tanggung jawab yang ada padanya (Mutiah et al., 2018). Semakin banyak petani yang memiliki pendidikan pada jenjang yang lebih tinggi atau bahkan hingga perguruan tinggi akan mendorong keberhasilan suatu kelompok untuk menumbuhkan kemandirian petani dalam berusaha.

Lama bertani (Y3) terhadap X3 memiliki nilai ExactSig. (2-sided) 0,042 < 0,05 maka $\mathrm{H}_{\mathrm{o}}$ diterima dan $\mathrm{H}_{\mathrm{a}}$ ditolak pada taraf nyata 95\% dengan nilai koefisien gamma 0,306, yang berarti terdapat korelasi positif yang sedang, dimana peningkatan peran Muhammadiyah dalam meningkatkan pengetahuan, sikap dan keterampilan (X3) mengikuti peningkatan jumlah petani yang memiliki pengalaman dalam mengelola usaha tani. Pengalaman dalam melakukan usahatani memberikan pandangan atau keputusan petani terhadap suatu hal yang perlu dilakukan (Yani et al., 2010). Berbeda dengan hasil penelitian Safitri et al. (2020) bahwa lama bertani tidak berpengaruh dengan keputusan petani untuk terlibat dalam sebuah kelompok. Pada penelitian ini petani dengan lamanya mengelola usaha tani lebih dari 10 tahun memiliki keterbukaan terhadap kelompok-kelompok atau lembaga-lembaga tertentu yang membantu dalam meningkatkan pengetahuan, sikap dan keterampilan produksi usaha tani. Peninjauan pengalaman petani untuk mendorong peran peningkatan pengetahuan, sikap dan keterampilan sebaiknya berada pada kategori cukup berpengalaman dengan lamanya mengelola usaha tani antara 5-10 tahun. Tetapi banyaknya petani berpengalaman memiliki kecenderungan banyaknya petani yang berusia lanjut sehingga kurang produktif. Sementara usia produktif akan mendorong peran sebuah kelompok untuk meningkatkan pengetahuan, sikap dan keterampilan masyarakat agraris sehingga banyaknya jumlah petani menurut lamanya dalam mengelola usaha tani dalam sebuah kelompok sebaiknya tidak lebih dari 10 tahun lamanya.

Tingkat penghasilan (Y2) terhadap X3 memiliki nilai ExactSig. (2-sided) 0,050 < 0,05 maka $\mathrm{H}_{0}$ diterima dan $\mathrm{H}_{a}$ ditolak pada taraf nyata $95 \%$ dengan nilai koefisien gamma 0,143 , yang berarti terdapat korelasi positif yang lemah, dimana peningkatan peran Muhamamdiyah dalam meningkatkan pengetahuan, sikap dan keterampilan (X3) mengikuti peningkatan jumlah petani dengan penghasilan yang rendah yakni kurang dari 1,5 juta perbulan. Penghasilan yang rendah mendorong kebutuhan petani pada kelompok yang mampu mengupayakan peningkatan kesejahteraan petani tanpa melihat status kelompok tersebut. Semakin banyak petani dengan penghasilan yang rendah akan semakin tinggi peran suatu kelompok dalam meningkatkan pengetahuan, sikap dan keterampilan masyarakat agraris.

Pengalaman berkelompok (Y6) terhadap X1 memiliki nilai ExactSig. (2-sided) 0,021 < 0,05 maka $\mathrm{H}_{0}$ diterima dan $\mathrm{H}_{\mathrm{a}}$ ditolak pada taraf nyata 95\% dengan nilai koefisien gamma 0,595 , yang berarti terdapat korelasi negatif yang sedang, dimana peningkatan peran Muhamamdiyah dalam meningkatkan produktifitas untuk menambah pendapatan (X1) mengikuti penurunan jumlah petani yang memiliki pengalaman dalam berkelompok. Semakin sedikit jumlah petani yang pernah terlibat pada suatu kelompok akan meningkatkan peran Muhammadiyah untuk meningkatkan produktifitas petani. Pengalaman berkelompok diukur dari tidak pernah, dan pernah atau sedang terlibatnya petani dalam kelompok tani tertentu. Petani yang sedang terlibat pada suatu kelompok memiliki kecenderungan untuk tidak terlibat pada kelompok lainnya, dengan alasan tiap kelompok memiliki agenda tersendiri yang saling berbeda dari tujuan maupun pelaksanaan kegiatannya, yang jika harus diikuti keseluruhannya akan membawa petani pada kesibukan yang mengganggu kegiatan usaha 
taninya. Semakin banyak petani yang tidak tergabung pada kelompok tani tertentu akan meningkatkan peran sebuah kelompok dalam meningkatkan produktifitas untuk menambah pendapatan masyarakat agraris.

Adapun peran Muhammadiyah sebagai unit kerjasama memiliki fungsi untuk memperkuat hubungan diantara sesama petani untuk secara bersama menghadapi berbagai masalah dalam pengembangan usaha tani.Hasil analisis peran Muhammadiyah sebagai unit kerjasama bagi petani di Kabupaten Bandung dapat dilihat pada Tabel 3.

Menurut Tabel 3 Muhammadiyah memiliki peran yang sangat baik sebagai unit kerjasama bagi petani. Pengurus Muhammadiyah di Kabupaten Bandung yang berprofesi sebagai petani memiliki keterlibatan secara langsung untuk bekerja sama menghadapi ancaman, tantangan, hambatan dan gangguan dalam mengelola usaha tani. Penelitian Effendy dan Apriani (2018) menyebutkan unit kerjasama dapat meningkatkan fungsi kelompok sebagai indikator paling tinggi yang meliputi suasana saling percaya, keterbukaan, dalam pembagian tugas/kerja, tanggung jawab anggota, bermusyawarah, bekerja sama menyediakan sarana dan jasa, melaksanakan kegiatan pelestarian lingkungan, kesepakatan bersama, kemitraan usaha dan pemupukan serta modal. Peran Muhammadiyah sebagai unit untuk memperkuat kerjasama antar kelompoktani dan terhadap pihak lain diwujudkan dalam kerjasama dengan institusi pendidikan tinggi, komunitas saudagar Muhammadiyah, dan para eksportir. Muhammadiyah telah memperkuat kerjasama diantara sesama petani pada kegiatan produksi dengan kebersamaan memilih komoditas yang dibudidayakan secara seragam, dan diatur agar berbeda dengan kawasan lainnya untuk menjaga stabilitas harga jual.

Hasil pengujian karakteristik petani yang diduga berkorelasi dengan peran Muhammadiyah sebagai unit kerjasama berdasarkan uji chi-square Pearson dapat dilihat pada Tabel 4. Tabel 4 menunjukkan karakteristik petani yang terdiri dari usia petani (Y1), tingkat pendidikan (Y2), lama bertani (Y3), status kepemilikan lahan (Y4), tingkat penghasilan (Y5), dan pengalaman berkelompok (Y6) memiliki nilai ExactSig. (2sided) > 0,05 maka $\mathrm{H}_{0}$ ditolak dan $\mathrm{H}_{\mathrm{a}}$ diterima,

Tabel 3.Peran Muhammadiyah sebagai unit kerjasama

\begin{tabular}{cllcccc}
\hline \multirow{2}{*}{ No Indikator } & \multicolumn{1}{c}{ Tingkat Peran } & \multirow{2}{*}{ Simpulan } \\
\cline { 3 - 5 } 1 & $\begin{array}{l}\text { Bekerja sama dalam menghadapi ancaman, } \\
\text { tantangan, hambatan dan gangguan (X4) }\end{array}$ & 33 & 39 & 3 & 180 & Sangat \\
Berperan \\
2 & $\begin{array}{l}\text { Tempat untuk memperkuat kerjasama antar } \\
\text { kelompok tani serta dengan pihak lain (X5) } \\
\text { Tempat untuk memperkuat kerjasama diantara }\end{array}$ & 39 & 33 & 3 & 186 & $\begin{array}{c}\text { Sangat } \\
\text { Berperan } \\
\text { Sangat } \\
\text { Berperan }\end{array}$ \\
\hline
\end{tabular}

Sumber: Data Primer, 2020

Tabel 4. Uji Chi-square dan Gamma Muhammadiyah sebagai unit kerjasama

\begin{tabular}{|c|c|c|c|c|c|c|}
\hline \multirow{3}{*}{ Karakteristik } & \multicolumn{6}{|c|}{ Peran Sebagai Unit Kerjasama } \\
\hline & \multicolumn{2}{|c|}{$\mathrm{X} 4$} & \multicolumn{2}{|c|}{ X5 } & \multicolumn{2}{|c|}{ X6 } \\
\hline & $\begin{array}{l}\text { ExactSig. } \\
\text { (2-sided) }\end{array}$ & Gamma & $\begin{array}{l}\text { ExactSig. } \\
\text { (2-sided) }\end{array}$ & Gamma & $\begin{array}{l}\text { ExactSig. } \\
\text { (2-sided) }\end{array}$ & Gamma \\
\hline Usia Petani & 0,065 & 0,253 & 0,123 & 0,008 & 0,379 & 0,053 \\
\hline Tingkat Pendidikan & 0,427 & 0,340 & 0,266 & 0,298 & 0,554 & 0,245 \\
\hline Lama Bertani & 0,277 & 0,294 & 0,699 & 0,127 & 0,745 & 0,194 \\
\hline Kepemilikan Lahan & 0,522 & $-0,017$ & 0,172 & 0,189 & 0,134 & 0,188 \\
\hline Tingkat Penghasilan & 0,641 & 0,019 & 0,675 & $-0,096$ & 0,398 & $-0,180$ \\
\hline $\begin{array}{l}\text { Pengalaman } \\
\text { Berkelompok }\end{array}$ & 0,304 & $-0,174$ & 0,471 & $-0,107$ & 0,058 & $-0,288$ \\
\hline
\end{tabular}

Sumber: Data Primer, 2020

Keterangan:

*signifikan $\alpha=0,05$

** signifikan $\alpha=0,01$ 
yang berarti tidak terdapat korelasi antara karakteristik petani dengan peran Muhamamdiyah sebagai unit kerjasama bagi petani di Kabupaten Bandung. Peran Muhammadiyah tercapai dengan sangat baik tersebut menurut kondisi banyaknya jumlah petani berusia produktif kurang dari 64 tahun dengan pendidikan sekolah dasar (SD) sampai sekolah menengah pertama (SMP), yang memiliki pengalaman dalam mengelola usaha tani kurang dari 5 tahun yang sebagian besar mengelola lahan milik sendiri, dan berpenghasilan kurang dari 1,5 juta per bulan, serta tidak memiliki pengalaman dalam berkelompok atau tidak sedang terlibat pada kelompok tani tertentu. Tercapainya peran yang sangat baik sebagai unit kerjasama tersebut menurut Maulana (2019) bahwa petani tidak mungkin dapat bekerja sendiri, dan menutup akses untuk berkomunikasi diantara sesama petani terlebih lagi dalam sebuah kelompok. Para petani yang telibat dalam sebuah kelompok saling membutuhkan informasi untuk kelancaran berbagai kegiatan usahataninya, dari mulai persiapan penanaman sampai pemasaran, dan termasuk melakukan pengembangan bentuk usaha tani pada komoditas lainnya sebagai alternatif saat terjadi penurunan produksi atau harga yang sedang anjlok.

Dalam peran sebagai unit produksi diharapkan Muhammadiyah mampu mendorong peningkatan produksi usaha tani dari segi kuantitas dan kualitas secara berkelanjutan yang dilakukan secara bersama diantara sesama petani dan pengurus Muhammadiyah. Hasil pengukuran terhadap tingkat peran tersebut dapat dilihat pada Tabel 5.

Menurut Tabel 5 peran Muhammadiyah sebagai unit produksi berusaha untuk mencapai skala ekonomi secara bersama dengan menyeimbangkan hasil dari segi kuantitas, kualitas maupun kontinuitas masih perlu ditingkatkan meskipun sebelumnya telah ada upaya penyediaan bantuan bibit dengan harga yang lebih murah dari Koperasi binaan Muhammadiyah, tetapi petani masih mengharapkan adanya bantuan dalam bentuk pemberian modal pinjaman yang dalam hal ini diharapkan dapat dilakukan dengan skema pengelolaan pinjaman dari Lembaga Zakat Infaq dan Shadaqah Muhammadiyah (Lazismu). Muhammadiyah juga perlu meningkatkan upaya untuk mengembangkan usaha tani yang dilakukan secara bersama sebagai suatu kesatuan usaha bersama melalui pembentukan forum yang bersifat formal yang beranggotakan para petani agar ada keterikatan yang jelas dengan legalitas untuk mengedepankan sikap kebersamaan diantara para petani dan pengurus dalam melaksanakan tanggungjawab untuk mengelola usaha tani yang lebih baik secara bersama dan berkelanjutan. Mengingat selama ini proses pengembangan usaha yang telah berjalan hanya dalam bentuk hubungan kepercayaan petani terhadap pengurus Muhamamdiyah sebagai tokoh yang diteladani dan dikenal sebagai petani sukses di Kabupaten Bandung.

Peran Muhammadiyah dalam mengembangkan usaha tani yang dilakukan oleh petani telah mencapai harapan dimana para petani bersama pengurus Muhammadiyah yang dipimpin oleh Ketua Pimpinan Daerah Muhammadiyah (PDM) Kabupaten Bandung melakukan impor, dan melaksanakan berbagai kegiatan penyuluhan dan bimbingan teknis terkait budidaya dari para pakar melalui skema kerjasama dengan institusi pendidikan tinggi untuk melaksanakan program pemberdayaan petani.

Tabel 5. Peran Muhammadiyah sebagai unit produksi

\begin{tabular}{clrrrrr}
\multicolumn{1}{c}{ Indikator } & \multicolumn{3}{c}{ Tingkat Peran } & \multirow{2}{*}{ Simpulan } \\
\cline { 3 - 5 } 1 & $\begin{array}{l}\text { Mencapai skala ekonomi secara bersama dengan } \\
\text { menyeimbangkan hasil produk dari segi kuantitas, } \\
\text { kualitas maupun kontinuitas (X7) }\end{array}$ & 29 & 38 & 8 & 171 & $\begin{array}{c}\text { Kurang } \\
\text { Berperan }\end{array}$ \\
2 & $\begin{array}{l}\text { Mengembangkan usaha tani yang dilakukan secara } \\
\text { bersama sebagai suatu kesatuan usaha bersama (X8) }\end{array}$ & 33 & 32 & 10 & 173 & $\begin{array}{c}\text { Kurang } \\
\text { Berperan } \\
\text { Sangat }\end{array}$ \\
3 & $\begin{array}{l}\text { Mengembangkan usaha tani yang dilakukan oleh } \\
\text { masyarakat (X9) }\end{array}$ & 39 & 27 & 9 & 180 & $\begin{array}{c}\text { Total } \\
\text { Berperan }\end{array}$ \\
\hline
\end{tabular}

Sumber: Data Primer, 2020 
Ritonga, U. S., Puspitasari, E. E. : Peran Muhammadiyah Dalam Pengembangan ...

Menurut Maulana (2019), kelompok tani dibentuk sebagai unit produksi bagi petani untuk meningkatkan pengetahuan dan keterampilan serta berbagi pengalaman untuk memecahkan berbagai masalah melalui penyuluh maupun antar kelompok tani. Tidak hanya hanya itu tetapi pembentukan kelompok juga diharapkan dapat mengembangkan segi permodalan, sarana produksi dan kemitraan. Peran Muhammadiyah sebagai unit produksi tersebut memiliki korelasi dengan karakteristik petani berdasarkan uji chi-square Pearson yang dapat dilihat pada Tabel 6.

Berdasarkan Tabel 6 diketahui tingkat pendidikan (Y2) terhadap X8 memiliki nilai ExactSig. (2-sided) 0,042 $<0,05$ maka $\mathrm{H}_{0}$ diterima dan $\mathrm{H}_{\mathrm{a}}$ ditolak pada taraf nyata $95 \%$ dengan nilai koefisien gamma 0,378, yang berarti terdapat korelasi sedang dimana peningkatan peran Muhammadiyah dalam mengembangkan usaha tani yang dilakukan secara bersama sebagai suatu kesatuan usaha bersama (X8) mengikuti peningkatan jumlah petani dengan tingkat pendidikan yang semakin tinggi. Petani dengan pendidikan yang semakin tinggi dalam hal ini sederajat atau lebih tinggi dari sekolah menengah atas (SMA) dapat memahami keterlibatannya pada sebuah kelompok sebagai sebuah proses untuk meningkatkan produksi yang perlu dilakukan secara bersama diantara sesama petani seperti yang dinyatakan oleh Sukanata et al. (2015) tingkat pendidikan petani memengaruhi sikap petani bekerja dalam sebuah kelompok. Dalam kebersamaan tersebut petani melaksanakan kegiatan produksi secara seragam pada komoditas tertentu untuk memudahkan kegiatan penyuluhan. Dengan demikian semakin banyak petani dengan pendidikan yang tinggi akan meningkatkan peran sebuah kelompok dalam mengembangkan usaha tani yang dilakukan secara bersama sebagai suatu kesatuan usaha bersama.

Lama bertani (Y3) terhadap X7 memiliki nilai ExactSig. (2-sided) 0,027 < 0,05 maka $\mathrm{H}_{0}$ diterima dan $\mathrm{H}_{\mathrm{a}}$ ditolak pada taraf nyata $95 \%$ dengan nilai koefisien gamma 0,532, yang berarti terdapat korelasi sedang, dimana peningkatan peran Muhammadiyah dalam mencapai skala ekonomi secara bersama dengan menyeimbangkan hasil produk dari segi kuantitas, kualitas maupun kontinuitas (X7) mengikuti peningkatan jumlah petani yang berpengalaman dalam melakukan usaha tani. Sebagian besar petani sampel di lokasi penelitian adalah petani dengan pengalaman kurang dari 5 tahun lamanya mengelola usaha tani. Sementara kategori petani yang sangat berpengalaman adalah petani yang mengelola usaha taninya lebih dari 15 tahun, yang tidak lebih banyak jumlahnya dari petani dengan pengalaman kategori menengah yakni 5-10 tahun. Pengalaman bertani tidak hanya meliputi kegiatan budidaya tanaman sebagai upaya dalam menghasilkan produk, tetapi termasuk kegiatan lainnya seperti manajemen permodalan dan pemasaran yang aspek pengembangannya membutuhkan keterlibatan pihak lain. Petani yang memiliki pengalaman menyadari pentingnya berpartisipasi dalam kelompok tertentu untuk kemudahan dan kelancaran produksi usaha taninya.

Tabel 6. Uji Chi-square dan Gamma peran Muhammadiyah sebagai unit produksi

\begin{tabular}{|c|c|c|c|c|c|c|}
\hline \multirow{3}{*}{ Karakteristik } & \multicolumn{6}{|c|}{ Peran Sebagai Unit Produksi } \\
\hline & \multicolumn{2}{|c|}{$\mathrm{X} 7$} & \multicolumn{2}{|c|}{$\mathrm{X} 8$} & \multicolumn{2}{|c|}{ X9 } \\
\hline & $\begin{array}{l}\text { ExactSig. } \\
\text { (2-sided) }\end{array}$ & Gamma & $\begin{array}{l}\text { ExactSig. } \\
\text { (2-sided) }\end{array}$ & Gamma & $\begin{array}{l}\text { ExactSig. } \\
\text { (2-sided) }\end{array}$ & Gamma \\
\hline Usia Petani & 0,679 & 0,148 & 0,271 & 0,108 & 0,866 & $-0,089$ \\
\hline Tingkat Pendidikan & 0,307 & 0,304 & $0,042 *$ & 0,378 & 0,435 & 0,090 \\
\hline Lama Bertani & $0,027^{*}$ & 0,532 & $0,046^{*}$ & 0,461 & 0,787 & 0,112 \\
\hline Kepemilikan Lahan & 0,163 & 0,026 & 0,574 & 0,164 & 0,057 & 0,394 \\
\hline $\begin{array}{l}\text { Tingkat } \\
\text { Penghasilan }\end{array}$ & 0,564 & $-0,120$ & 0,532 & 0,014 & $0,025^{*}$ & $-0,258$ \\
\hline $\begin{array}{l}\text { Pengalaman } \\
\text { Berkelompok }\end{array}$ & 0,055 & $-0,279$ & 0,214 & $-0,245$ & 0,518 & 0,012 \\
\hline
\end{tabular}

Sumber : Data Primer, 2020

Keterangan:

*signifikan $\alpha=0,05$

**signifikan $\alpha=0,01$ 
Semakin banyak petani yang memiliki pengalaman dalam mengelola usaha tani akan meningkatkan peran sebuah kelompok dalam mencapai skala ekonomi secara bersama dengan menyeimbangkan hasil produk dari segi kuantitas, kualitas maupun kontinuitas.

Lama bertani (Y3) terhadap X8 memiliki nilai ExactSig. (2-sided) 0,046 $<0,05$ maka $\mathrm{H}_{\mathrm{o}}$ diterima dan $\mathrm{H}_{\mathrm{a}}$ ditolak pada taraf nyata $95 \%$ dengan nilai koefisien gamma 0,461, yang berarti terdapat korelasi sedang, dimana peningkatan peran Muhammadiyah dalam mengembangkan usaha tani yang dilakukan secara bersama sebagai suatu kesatuan usaha bersama (X8) mengikuti peningkatan jumlah petani yang berpengalaman dalam mengelola usaha tani. Petani yang berpengalaman mengetahui bahwa kebersamaan akan mendukung ketersediaan informasi bagi usaha taninya yang meliputi informasi ketersediaan sarana produksi, teknik budidaya hingga pemasaran hasil yang secara langsung seringkali diterima dari petani lainnya dan pengurus Muhammadiyah. (Sukanata et al., 2015) bahwa pengalaman berusahatani berhubungan dengan tingkat kematangan para petani yang menentukan kesiapan serta keputusan dalam menghadapi suatu permasalahan pada usaha taninya secara sendiri atau berkelompok. Dengan demikian semakin banyak petani yang memiliki pengalaman dalam mengelola usaha tani akan meningkatkan peran sebuah kelompok dalam mengembangkan usaha tani yang dilakukan secara bersama sebagai suatu kesatuan usaha bersama.

Tingkat penghasilan (Y5) terhadap X9 memiliki nilai ExactSig. (2-sided) 0,025 < 0,05 maka $\mathrm{H}_{0}$ diterima dan $\mathrm{H}_{\mathrm{a}}$ ditolak pada taraf nyata 95\% dengan nilai koefisien gamma 0,258, yang berarti terdapat korelasi negatif yang lemah, dimana peningkatan peran Muhammadiyah dalam mengembangkan usaha tani yang dilakukan oleh masyarakat (X9) mengikuti penurunan jumlah petani yang berpenghasilan tinggi. Semakin kecil jumlah petani dengan penghasilan yang tinggi menjadi gambaran tingkat kesejahteraan petani yang rendah, karena skala luas lahan produksi yang kecil, status kepemilikan lahan yang merupakan lahan sewa, modal yang sedikit, kurangnya kemampuan teknis dalam memproduksi, serta pemasaran yang belum efektif. Dengan kondisi tersebut petani akan berusaha untuk melakukan pengembangan melalui keterlibatannya dalam sebuah kelompok sebagai pihak yang dapat membantu. Semakin banyak petani dengan penghasilan yang rendah akan meningkatkan peran sebuah kelompok dalam mengembangkan usaha tani yang dilakukan masyarakat agraris.

\section{KESIMPULAN}

Muhammadiyah sebagai kelas belajar berperan sangat baik dalam meningkatkan produktifitas untuk menambah pendapatan petani, dan menjadi wadah belajar mengajar bagi petani guna meningkatkan pengetahuan, sikap dan keterampilan petani. Karakteristik petani yang terdiri dari usia petani, lama bertani, dan tingkat penghasilan petani berkorelasi secara positif dengan peran dalam meningkatkan pengetahuan, sikap dan keterampilan. Sementara pengalaman berkelompok memiliki korelasi negatif dengan peran dalam meningkatkan produktifitas untuk menambah pendapatan petani.

Muhammadiyah sebagai unit kerjasama bagi petani ditunjukkan dari peran yang sangat baik dalam mengembangkan sikap bekerja sama menghadapi ancaman, tantangan, hambatan dan gangguan usahatani, menjadi tempat untuk memperkuat kerjasama antar kelompok tani serta dengan pihak lain, dan menjadi tempat bagi para petani untuk memperkuat kerjasama diantara sesama petani yang tidak berkorelasi dengan usia petani, tingkat pendidikan, lama bertani, status kepemilikan lahan, tingkat penghasilan, dan pengalaman berkelompok. Muhammadiyah sebagai unit produksi memiliki peran yang sangat baik dalam mengembangkan usaha tani. Karakteristik petani yang berkorelasi dengan peran tersebut terdiri dari tingkat pendidikan memiliki korelasi positif dengan peran dalam mengembangkan usaha tani yang dilakukan secara bersama sebagai suatu kesatuan usaha bersama; lama bertani memiliki korelasi positif dengan peran dalam mencapai skala ekonomi secara bersama dengan menyeimbangkan hasil produk dari segi kuantitas, kualitas maupun kontinuitas dan dengan peran dalam mengembangkan usaha tani yang dilakukan secara bersama sebagai suatu kesatuan usaha bersama. Sementara tingkat penghasilan 
memiliki korelasi negatif dengan peran dalam mengembangkan usaha tani yang dilakukan oleh masyarakat agraris.

\section{UCAPAN TERIMA KASIH}

Terimakasih disampaikan kepada Majelis Pendidikan Tinggi, Penelitian dan Pengembangan Pimpinan Pusat Muhammadiyah atas Hibah Risetmu yang diberikan sehingga penelitian ini dapat terlaksana.

\section{DAFTAR PUSTAKA}

Anantanyu, S. (2011). Kelembagaan petani: peran dan strategi pengembangan kapasitasnya. SEPA, 7(2), 102-109.

Ardita, DWP, S., \& Widjanarko, D. (2017). Kinerja penyuluh pertanian menurut persepsi petani: studi kasus di Kabupaten Landak. Journal of Vocational and Caree Education, 2(1), 1-8. https:// doi.org/10.15294/jvce.v2i1.10908.

Bungo, S. (2014). Pendekatan dakwah kultural dalam masyarakat plural. Jurnal Dakwah Tabligh, 15(2), 209-219. https://doi.org/ 10.24252/jdt.v15i2.349.

Damanik, I. P. (2013). Faktor-faktor yang memengaruhi dinamika kelompok dan hubungannya dengan kelas kemampuan kelompok tani di Desa Pulokencana Kabupaten Serang. Jurnal Penyuluhan, 9(1), 31-40. https://doi.org/10.25015/ penyuluhan.v9i1.9856.

Effendy, L., \& Apriani, Y. (2018). Motivasi anggota kelompok tani dalam peningkatan fungsi kelompok. Jurnal Ekonomi Pembangunan, 4(2), 10-24. https://doi.org/10.35906/jep01.v4i2.270

Gio, P. U., \& Caraka, R. E. (2018). Pedoman Dasar Mengolah Data Dengan Program Aplikasi Statistika Statcal. Medan: USU Press.

Habibullah. (2020). Peran pusat kesejahteraan sosial dalam pelayanan sosial terintegratif. Sosio Konsepsia, 9(3), 295-306. https://doi.org/10.33007/ska. v9i3.2043.

Hasan, S., Tilaar, W., \& Karamoy, L. T. (2016). Pengaruh penyuluhan pertanian dalam aspek lingkungan, ekonomi dan teknologi pada petani padi sawah di Kecamatan Modayag. AgriSosioEkonomi Unsrat, 12(3A), 165-178. https://doi.org/10.35791/agrsosek.12.3A. 2016.14388 .

Impal, M., L.S, B. O., \& Moniaga, V. R. B. (2017). Peranan kelompok tani “tenggang rasa” terhadap pengembangan tanaman kakao di Desa Inomunga, Kecamatan Kaidipang, Kabupaten Molaang Mongondow Utara. AgriSosioEkonomi Unsrat, 13(2), 97-112.

Latifarruhma, E., Dalmiyatun, T., \& Mardiningsih, D. (2019). Peran kelompok tani akasia terhadap keberdayaan petani padi sawah di Desa Cabean Kecamatan Demak Kabupaten Demak Jawa Tengah. SOCA: Jurnal Sosial, Ekonomi Pertanian, 13(3), 317330. https://doi.org/10.24843/soca.2019 .v13.i03.p03.

Manatar, M. P., H. Laoh, E., \& Mandei, J. R. (2017). Pengaruh status penguasaan lahan terhadap pendapatan petani padi di Desa Tumani, Kecamatan Maesaan, Kabupaten Minahasa Selatan. AgriSosioEkonomi Unsrat, 13(1), 55-64.

Maulana, K. (2019). Peran kelompok tani terhadap kondisi perekonomian petani. Jurnal Pendidikan Teknologi Pertanian, 5(2), 61-66.

Muchtar, L. O. M., Prajarto, N., \& Subejo. (2013). Model kemitraan pembangunan pedesaan di Kabupaten Kolaka Provinsi Sulawesi Tenggara. Agroekonomika, 2(1), 27-39. https://doi.org/10.21107/ agriekonomika.v2i1.663.

Mulyadi, M. (2012). Organisasi masyarakat (ormas) dompet dhuafa dalam perspektif pemberdayaan masyarakat. Aspirasi, 
Ritonga, U. S., Puspitasari, E. E. : Peran Muhammadiyah Dalam Pengembangan ...

3(2), 167-178. https://doi.org/10.22212 /aspirasi.v3i2.267.

Mulyadi, M. (2015). Perubahan sosial masyarakat agraris ke masyarakat industri dalam pembangunan masyarakat di Kecamatan Tamalate Kota Makassar. Jurnal Bina Praja, 7(4), 311-322. https://doi.org/https://doi.org/10.21787/j bp.07.2015.311-321.

Mutiah, A., Abdullah, A., \& Nurlaelah, S. (2018). Identifikasi peranan kelompok sebagai wahana kerja sama pada kelompok peternak sapi potong pada peternakan rakyat. Agripet, 18(1), 57-62. https://doi.org/https://doi.org/10.17969/a gripet.v18i1.10971

Nugroho, F. M., Satmoko, S., \& Karno. (2018). Peran kelompok tani terhadap usahatani padi di Kecamatan Sale Kabupaten Rembang. Journal of Agro Complex, 2(2), 109-119. https://doi.org/10.14710 /joac.2.2.109-119.

Palar, R. H., Ngangi, C. R., \& Susana, B. O. L. (2019). Peran kelompok tani terhadap anggota kelompok tani Kelelelondei Indah di Desa Ampreng Kecamatan Langowan Barat. Agri-SosioEkonomi Unsrat, 15(1), 37-44. https://doi.org/ 10.35791/agrsosek.15.1.2019.22783.

Prasetia, R., Hasanuddin, T., \& Viantimala, B. (2015). Peranan kelompok tani dalam peningkatan pendapatan petani kopi di Kelurahan Tugusari Kecamatan Sumberjaya Kabupaten Lampung Barat. JIIA, 3(3), 301-307. https://doi.org/ 10.23960/jiia.v3i3.\%25p.

Pratama, B. P., Sayamar, E., \& Tety, E. (2016). Peranan kelompok tani dalam meningkatkan pendapatan petani swadaya kelapa sawit di Desa Bukit Lingkar Kecamatan Batang Cenaku Kabupaten Indragiri Hulu. Jom Faperta, 3(2), 1-12.

Priyono. (2016). Metode Penelitian Kuantitatif (Revisi). Sidoarjo: Zifatama Publishing.
Ramadoan, S., Muljono, P., \& Pulungan, I. (2013). Peran PKSM dalam meningkatkan fungsi kelompok tani dan partisipasi masyarakat di Kabupaten Bima, NTB. Jurnal Penelitian Sosial dan Ekonomi Kehutanan, 10(3), 199-210.

Safitri, N., Istiqomah, Widayaningsih, N., \& Purnomo, S. D. (2020). Analisis keanggotaan petani dalam kelompok tani: studi kasus kelompok pembudidaya ikan "ulam sari" Desa Kalikidang, Sokaraja, Banyumas. Jurnal Sosial Ekonomi Pertanian, 13(1), 65-72.

Sidipurwanty, E. (2016). Pengendalian alih guna tanah sawah ke nonpertanian di Kabupaten Bandung, Jawa Barat melalui peraturan desa. Jurnal Masyarakat \& Budaya, 18(3), 387-414.

Simanjuntak, O. V., Subejo, S., \& Witjaksono, R. (2018). Partisipasi petani dalam program gerakan penerapan pengelolaan tanaman terpadu padi di Kecamatan Kalasan Kabupaten Sleman. Agro Ekonomi, 27(1), 20-37. https://doi.org /10.22146/jae.22693.

Sofiyudin, A., Salampessy, M. L., \& Anggraeni, D. (2016). Hubungan karakteristik masyarakat dengan peran partisipasi dalam program Green Wall di Taman Nasional Gunung Gede Pangrango. Nusa Sylva, 16(2), 89-97.

Sukanata, I. K., Dukat, \& Yuniati, A. (2015). Hubungan karakteristik dan motivasi petani dengan kinerja kelompok tani (studi kasus Desa Cisaat Kecamatan Dukupuntang). Jurnal Agrijati, 28(1), 17-34.

Wardani. (2017). Peranankelompoktani dalam meningkatkan produktivitas usahatani (kasus di wilayah BP3K Sukalarang, Sukabumi). Jurnal Penyuluhan Pertanian, 12(1).81-88. https://doi.org/ 10.51852/-.v12i1.343.

Wati, F., Rasmikayati, E., \& Saefudin, B. R. (2020). Analisis hubungan karakteristik anggota kelompok tani dengan 
Ritonga, U. S., Puspitasari, E. E. : Peran Muhammadiyah Dalam Pengembangan ...

penerapan teknologi off season pada kegiatan usahatani mangga di Kecamatan Sedong, Kabupaten Cirebon, Jawa Barat. Jurnal Ekonomi Pertanian dan Agribisnis, 4(4), 715-727. https://doi. org/10.21776/ub.jepa.2020.004.04.02.

Yani, D. E., ES, L., \& Noviyanti, R. (2010). Persepsi anggota terhadap peran kelompok tani dalam meningkatkan kemampuan penguasaan teknologi budidaya belimbing. Jurnal Matematik, Sains, dan Teknologi, 11(2), 133-145.

Zaini, A. (2017). Dakwah dan pemberdayaan masyarakat pedesaan. Jurnal Ilmu Dakwah, 37(2), 284-301. https://doi.org /10.21580/jid.v37.2.2708. 